\title{
Avoiding Corrosion Problems in Florida ${ }^{1}$
}

Virginia Peart ${ }^{2}$

Corrosion is a naturally occurring deterioration of a metal caused by reaction with its environment and especially with oxygen. The result is the production of brown rust on iron or steel, white spots or surface discoloration on aluminum and blue or green layers on copper. Moisture, oxygen and a salt (e.g. sodium chloride) all contribute to the corrosion process. In a humid climate, especially in coastal areas where moisture is saline or salty, corrosion can occur readily.

\section{What Causes Corrosion?}

Corrosion is essentially a process of oxidation, or a return of the metal to its oxidized state as an ore. The rusting of iron is a typical example of the process of corrosion where a metal tends to return to its oxidized state.

Corrosion is the result of an electrochemical reaction between a metal and its surroundings. Consider what happens when you use a battery. A battery has two electrodes, an anode and a cathode. When a connection is made between the two electrodes, electrons flow from the anode to the cathode through this connection. The anode corrodes in this process. When the anode is completely corroded, the battery is dead.
When the surface of a metal or of two different metals connected together is exposed to a corrosive liquid, such as salt water or water with dissolved oxygen, a micro-battery is established. The surface of the single metal or of the less-resistant of the two metals will disintegrate.

In a single metal, corrosion sometimes occurs as a result of deformation of the metal's crystalline structure. A current can be induced between two crystalline "grains" at a surface of the metal when the metal is exposed to a corrosive liquid such as water with dissolved salt or oxygen. This type of corrosion can occur quickly on untreated iron and steel.

Different metals, when used together, have different tendencies to corrode. The corrosion series shown in Table 1 lists metals from the least resistant to the most resistant. The farther apart the two metals are in this series, the greater is the potential for corrosion. The material higher in the list becomes the anode of the micro-battery to the material below it and will corrode. For example, joining aluminum and brass would readily produce corrosion in the aluminum when moisture is present.

1. This document is FCS 3141, one of a series of the Department of Family, Youth and Community Sciences, Florida Cooperative Extension Service, Institute of Food and Agricultural Sciences, University of Florida. Publication date: January 2003. First published: February 1989. Reviewed: January 2003. Please visit the EDIS Web site at http://edis.ifas.ufl.edu

2. Written by Virginia Peart, former Associate Professor, Housing, Department of Family, Youth and Community Sciences, Cooperative Extension Service, Institute of Food and Agricultural Sciences, University of Florida, Gainesville, 32611 and reviewed by Nayda I. Torres, Professor, Family and Consumer Economics, Department of Family, Youth and Community Sciences, Cooperative Extension Service, Institute of Food and Agricultural Sciences, University of Florida and Dale Dorman, Extension Housing and Environment Specialist - Emeritus, Cooperative Extension Service, University of Georgia. 
Table 1.

\section{Corrosion Series}

Least-resistant

Magnesium

Zinc

Aluminum

Untreated iron or steel

Solders (lead-tin)

Copper, brass, bronze

Stainless steel

Silver

Platinum

Most-resistant

When two dissimilar metals are joined or a metal fastener is used to join metal parts, care should be taken to use metals that will not unintentionally accelerate corrosion. When purchasing metal furniture and other items to be used where they will be exposed to humidity, like that in the Florida atmosphere, attention to the use of metal combinations is important. The chart in Table 2 may be a useful guide.

Table 2.

\begin{tabular}{|c|c|c|}
\hline \multicolumn{3}{|c|}{ Metal to Metal Joints } \\
\hline \multirow[t]{2}{*}{ Metal Part } & \multicolumn{2}{|c|}{ Fastener Type } \\
\hline & Bad & Good \\
\hline Aluminum* & $\begin{array}{c}\text { Copper, Brass, } \\
\text { Steel }\end{array}$ & $\begin{array}{c}\text { Aluminum, } \\
\text { Stainless Steel }\end{array}$ \\
\hline $\begin{array}{c}\text { Copper, Brass, } \\
\text { Bronze }\end{array}$ & $\begin{array}{c}\text { Steel }^{*} \\
\text { Aluminum* }^{*}\end{array}$ & $\begin{array}{c}\text { Stainless } \\
\text { Steel, Brass, } \\
\text { Copper }\end{array}$ \\
\hline $\begin{array}{l}\text { Galvanized } \\
\text { Steel }^{*} \text { (Zinc- } \\
\text { plated) }\end{array}$ & $\begin{array}{c}\text { Stainless Steel, } \\
\text { Brass }\end{array}$ & $\begin{array}{c}\text { Aluminum, } \\
\text { Galvanized } \\
\text { Steel }\end{array}$ \\
\hline Steel* & $\begin{array}{l}\text { Copper, Brass, } \\
\text { Stainless Steel }\end{array}$ & $\begin{array}{l}\text { Galvanized } \\
\text { Steel, Steel }\end{array}$ \\
\hline
\end{tabular}

\section{Corrosion Effects on Common Household Metals}

\author{
Iron and Steel (Untreated)
}

Rust, iron oxide, is often very porous to oxygen and water. Once corrosion begins, it can continue until the metal is entirely corroded. Iron and steel must be protected if they are to be exposed to moisture or water. Paint or enamel coatings on untreated iron or steel provide protection from corrosion, but must be kept in good repair. Scratches on appliances placed in unair-conditioned spaces in Florida will soon show rust. Appliance dealers have a lacquer that can be used to cover and protect scratches from rust.

To prevent rusting, cast iron or steel cookware should be coated with oil when not used regularly.

When a zinc coating is used on steel, the zinc will corrode, but will protect the steel. It is used as a sacrificial coating to protect the steel.

\section{Aluminum}

Although aluminum corrodes easily, it develops a thin film of aluminum oxide that acts as a barrier to continued corrosion. Shiny aluminum cookware can be kept shiny, if washed and dried promptly after use. Otherwise, water spots will permit oxidation which cannot be easily removed. The spots may leave a ring stain as the exterior areas of a water drop may hold more oxygen and show more corrosion.

Since an aluminum oxide coating is often considered unattractive, aluminum outdoor furniture and other aluminum surfaces exposed to a moist atmosphere can be protected with a coat of wax. Aluminum can also be painted to protect its surfaces from corrosion. If an oxide has formed on aluminum, remove it with fine steel wool before painting. 
When aluminum is exposed to salty moisture, as occurs in coastal regions, pitting will result. This causes problems in the aluminum trim in sliding glass doors and can make them difficult to slide. Aluminum cookware also can pit when food or salty water is left in contact.

An aluminum pan will corrode more easily if silver (a metal lower in the corrosion series) is soaked or washed in it. The silver, on the other hand, will show less tarnish as the silver oxide will return to its metallic form.

Aluminum reacts with both acids and alkaline solutions. When an alkaline food or liquid is heated in aluminum, a dark oxide if formed. Heating an acidic food or liquid (tomatoes, apples) will restore the aluminum to its shiny, metallic form.

\section{Copper}

Copper readily forms an oxide coating in almost any atmosphere. The black oxide coating that forms acts much like a coat of paint in preventing air from reaching the metal, and thus stops corrosion. The oxide coating on copper can be removed by rubbing the surface with a paste made of salt and vinegar or lemon juice. This process chemically removes the oxide.

Commercial products are also available to restore copper to its natural metallic color. Follow manufacturer's instructions carefully as the ingredients used can be dangerous to breathe.

A clear coating (lacquer) is sometimes used on new items to prevent tarnishing. Copper items with a coating should be cleaned by dusting or washing with a damp cloth and drying.

\section{Brass}

Brass is an alloy of copper and zinc in various proportions and will corrode at a faster rate than copper, but is cheaper and stronger. It is better suited to some purposes.
Cleaning methods for brass are the same as for copper.

Brass or bronze fabricated by mechanical means such as forging, stamping, drawing or extruding can crack when exposed to an atmosphere with ammonia. Example: A silverplated brass or bronze goblet might crack if stored in a china cabinet after the interior cabinet glass has been cleaned recently with an ammonia product.

\section{Bronze}

Bronze is an alloy of copper and tin. Bronze, like brass, is stronger and cheaper than copper, but will corrode more readily than copper.

Cleaning methods for bronze are the same as for copper.

\section{Silver}

Tarnishing of silver occurs more quickly in a moist than a dry environment. Traces of sulfur compounds in the atmosphere, which occur around materials such as rubber, can speed this process. Silver cloth, a cloth treated as a corrosion inhibitor, can protect silver from tarnishing.

Tarnished silver can be restored by wrapping loosely in aluminum foil and processing through a dishwasher cycle with dishwasher detergent. The oxide on the silver will return to its metallic state and the aluminum will become coated with aluminum oxide. On silver items with dark oxide in pattern crevices to enhance the pattern, the dishwasher/aluminum foil process should not be used as it will remove all the dark oxide.

Commercial products are also available to polish silver oxide from silver. 


\section{In Summary}

Metals are subject to corrosion in an environment that provides moisture, oxygen and salts that can form an electrolyte. An electrical path through the electrolyte between two dissimilar metals will elevate the rate of corrosion of the least resistant metal in the corrosion series. To protect metals from corrosion:

- Keep the environment in which metals are used and stored dry.

- Avoid the use of two dissimilar metals together where moisture is present or where a current can flow between them.

- Paint, enamel, wax or a tight, vapor-proof covering can protect metals. Coatings such as chromium, zinc or aluminum are used to protect steel.

- Avoid prolonged contact of metals with salt or any food or other substance that has salt in it. Rinse well after use. 